\title{
Overall Store Price Image (OSPI), Antecedents, and Its Effect on Repurchase Intention
}

\author{
Liana Vinsensia Sihotang and Jeanne Ellyawati \\ Faculty of Business and Economics, Universitas Atma Jaya Yogyakarta, Indonesia \\ Email Corresponding author: \\ j.ellyawati@uajy.ac.id
}

\begin{abstract}
This study aims to examine the influence of store price image which is consisting of price fairness images, price pleasure images, price rewards images, price value images on overall store price images (OSPI), and repurchase intentions. The study also examines the role of moderation variables, store image, and price sensitivity on the relationship between OSPI and repurchase intentions. Several 423 respondents were recruited using a purposive sampling method. The structured questionnaire was distributed offline to respondents using paper and pencil test techniques. Data is processed using variant-based SEM (SmartPLS). The results showed that all antecedent variables of store price images have a positive effect on OSPI. Furthermore, OSPI effect positively on repurchase intentions. The study findings show that store image and price sensitivity did not moderate the relationship between OSPI and repurchase intention. This study found interesting results that store image and price sensitivity are mediating variables.
\end{abstract}

Keywords: overall store price image (OSPI), repurchase intentions, store image, price sensitivity.

\begin{abstract}
Abstrak: Studi ini bertujuan untuk menguji pengaruh citra harga toko yang terdiri dari price fairness image $(\mathrm{PFI})$, price pleasure image $(\mathrm{PPI})$, price rewards image $(\mathrm{PRI})$, price value image (PVI) pada overall store price image (OSPI) dan niat beli ulang. Studi ini juga menguji peran moderasi citra toko dan sensitivitas harga pada hubungan OSPI dan niat pembelian kembali. Sampel dikumpulkan sebanyak 423 reponden dengan menggunakan metode perposive sampling. Kuesioner terstruktur didistribusikan secara offline kepada responden dengan teknik paper and pencil test. Data diolah dengan menggunakan alat statistik SEM berbasis varian yaitu SmartPLS. Hasil studi ini menunjukkan bahwa semua variabel antesenden citra harga toko berpengaruh positif terhadap OSPI. Selanjutnya OSPI berpengaruh pada niat beli ulang secara positif. Hasil temuan studi menunjukkan bahwa variable citra toko dan sensitivitas harga tidak memoderasi hubungan OSPI dan niat beli ulang. Temuan yang menarik dalam studi ini bahwa citra toko dan sensitivitas harga justru merupakan variabel pemediasi.
\end{abstract}

Kata Kunci: overall store price image (OSPI), niat beli ulang, citra toko, sensitivitas harga. 


\section{INTRODUCTION}

Every day there will always be community shopping activities, both products, and services. Of course, it is commonplace if the consumption market is in great demand by business actors, especially in the retail sector. Indonesia is a very potential market, with a population of 265 million in 2018 and is predicted to reach 305.65 million in 2035 (BPS, 2014), so the market share of retail business in Indonesia is still wide open. This encourages business people to target Indonesia as a profitable market share.

Indonesia is the most potential market in ASEAN with spending in 2015 amounting to IDR 4,369 trillion for products other than food and IDR 1,930 trillion for food products. Meanwhile, the average growth of the modern retail industry in 2015 for the fast-moving consumer good category reached $10.8 \%$, with $11 \%$ growth in the mini-market segment and $10.6 \%$ in the supermarket/hypermarket segment (Duniaindustri.com., 2015). However, since 2016, offline retail sales growth in Indonesia has tended to decline (CEIC, 2019), 2019). Many retailers have gone out of business, such as 7-Eleven, which since 2017 has officially closed all its outlets in Indonesia (Rosyadi, 2017). Meanwhile, several retailers are trying to streamline their operational costs by closing several offline outlets and then switching to online such as MatahariMall (Rachmatunnisa, 2018). One of the causes is the emergence of the policy of Presidential Regulation Number 44 of 2016 concerning permits for foreign investors to invest in the retail sector in Indonesia (Primadhyta, 2016). Several foreign retailers that entered Indonesia include Circle-K from Canada, Carrefour from France, Giant from Malaysia, and others.

In marketing management, two strategies can be used to compete in a competitive environment, namely differentiation and cost leadership (Uslu and Huseynli, 2018). Differentiation is a strategy that creates unique value, while cost leadership is more directed at cutting unnecessary operational costs to offer better prices than competitors. According to previous studies, for daily necessities retailers, marketers need to create low prices store image (Koschmann and Isaac, 2018). Creating a store price image requires a complex process, namely by combining multi-dimensional prices. Previous research (Chang and Wang, 2014) stated that the store price image is a mixture of dimensions, namely price value image (PVI), price reward image (PRI), price fairness image (PFI), and a price image that is pleasing to a price pleasure image. PPI). Another study (Graciola et al., 2018) also proved that store price images are a mix of quality dimensions, perceived value, perceived price levels, fair prices, positive emotions, negative emotions, and symbolic dimensions. Meanwhile, according to (Franjković et al., 2017), there are three aspects that affect the store price image, namely the customer perceived price level, price strategy, and price promotion. Price is not only used as a store strategy but is also part of the store brand.

This multidimensional complex makes consumers more sensitive to price. Previous studies (Graciola et al., 2018) stated that price sensitivity will strengthen the effect of store price images on consumer repurchase intentions. However, price sensitivity varies depending on the type of product or service, for example, beverage products are not influenced by price sensitivity (Uslu and Huseynli, 2018). It is also stated that sales promotion can increase price sensitivity because consumers often associate price with quality (Büttner et al., 2014). Consumer response to promotions in retail stores also depends on the image of the store. Promotion is like a double-edged sword and depends 
on the image of the retail store. Promotion in a retail store will be attractive if the image of the retail store is good. Conversely, doubts will arise on a low store image because consumers think that promotion is only for low product quality (Chang and Wang, 2014).

Previous studies stated that promotion determination has an important role in shaping prices and consumer perceptions of store image (Chang and Wang, 2014). Store image is said to moderate the influence of OSPI on repurchase intention. A positive store image will strengthen the influence of OSPI on repurchase intentions. A positive store image presents consumers' perceptions of the shopping environment, services, and perceptions of high product quality (Akter and Ashraf, 2016). This study wants to investigate why a traditional retail store can compete with modern chain retail stores such as Indomaret, Alfamart, and so on. What are the factors that determine the overall store price image and their effect on consumer repurchase intention?

\section{THEORETICAL REVIEW}

Overall store price image (OSPI). Previous studies stated that price images are an important topic because consumers visit stores based on subjective beliefs and feelings that cause these stores to be perceived as an expensive or cheap store category (Lombart et al., 2016). Thus, the price image is the attitude of the buyer towards various price levels (Koschmann and Isaac, 2018). According to (Paramananda and Sukaatmadja, 2018) price perception is a consumer judgment in the form of emotions related to the price offered, whether the price is logical, acceptable, or justified. The pricing strategy greatly affects the price image in retail stores, either with everyday low pricing or high/low pricing (Kimpel and Friedrich, 2015). The price image is also influenced by non-price factors such as retailer size, shopping atmosphere or environment, and product variation. So, it can be concluded that OSPI is a belief about the whole image of the price that consumers feel at the retail store (Roth et al., 2017). OSPI can be reflected from four dimensions, namely (Chang and Wang, 2014), namely: price fairness image, price pleasure image, price reward image, and price value image.

Price fairness image (PFI). The notion of fairness in economics is taken from equity theory, which is a ratio between what is obtained and what is spent and is based on normative thinking that is generally accepted by society (Ellyawati, 2017). Consumers will consider the price of a product to be fair if it is reasonable, acceptable, or justified by consumers (Chang and Wang, 2014; Graciola et al., 2018; Nguyen and Meng, 2016). Perceived price fairness according to (Jin et al., 2016) as a subjective evaluation of what consumers have spent to get a product. Consumers perceive that the price is fair if the value of the product is considered to be higher than the costs incurred. Besides, retailers who consistently provide good service will be considered fairer than retailers who are inconsistent in service quality (Jin et al., 2016) and price transparency is also part of price fairness (Graciola et al., 2018).

Price pleasure image (PPI). In setting prices, retailers must pay attention to consumer reactions, and consumer reactions can be seen from consumer emotions (Ludwig et al., 2017). Thus retailers need to be able to manage consumer emotions well. Price pleasure image is consumer response to prices in retail stores such as feeling happy or angry when 
making a purchase. It is said that consumers will respond with positive emotions when given a surprise (Ludwig et al., 2017), and a decrease in price (Chang and Wang, 2014). According to (Jin et al., 2016), a positive emotional response arises because of the fulfillment of consumer expectations. It was also stated that positive emotions will affect long-term buying patterns and consumers tend to recommend the retail stores to others (Ludwig et al., 2017).

Price rewards image (PRI). Price reward image is the consumer's perception of the benefits offered by retail stores (Chang and Wang, 2014). Consumers tend to prefer benefits that consumers get immediately, such as lower prices or gift incentives. Retailers can target specific consumer segments to be rewarded. In general, companies tend to give discounts to new customers. However, (Lee and Fay, 2017) examines the lower prices for loyal customers as a form of appreciation, for example through membership cards that provide lots of promotions (Lee and Fay, 2017). Meanwhile, another study stated that besides price discounts, companies can provide rewards based on the frequency and number of purchases, as well as other points systems to regular customers (Jones et al., 2015).

Retailers differentiate promotions into two types, namely monetary promotions and non-monetary promotions. Previous studies have suggested that monetary promotions such as discounts/coupons are more effective for short-term marketing but can harm price sensitivity and brand equity (Büttner et al., 2014). On the other hand, non-monetary promotions such as sweepstakes or gifts provide more hedonic benefits such as entertainment but have no effect on price sensitivity or brand equity, lower market share, and lower attractiveness. According to (Santini et al., 2015), monetary promotion is an efficient alternative for consumers because it can reduce the risk of consumer loss.

Price value image (PVI). According to (Tarhini et al., 2017), the price value is the ratio between the benefits obtained compared to the value spent by the consumer. It can also be stated that this is a trade-off between consumer sacrifice and product utility (Chang and Wang, 2014). Consumers will try to maximize the value of money spent, obtain products with better quality and product acquisition at lower prices (Paramananda and Sukaatmadja, 2018). The price tag is said to make it easy for consumers to choose products (Roth et al., 2017). According to (Seim et al., 2017), detailed price information will help consumers in their purchasing decisions, and this will have an impact on increasing demand for these products.

Repurchase intention (RI). Repurchase intention is defined as the intention to repurchase products at the same store by considering the current and future situation of consumers (Uslu and Huseynli, 2018; Chang and Wang, 2014). The concept of repurchasing according to (Graciola et al., 2018) is the intention to revisit the store by paying attention to positive emotional relationships and consumer satisfaction levels. A study conducted by (Uslu and Huseynli, 2018) stated that a fair price will influence consumers to make repeat purchases in the future.

Store image (SI). Store image is one of the important factors that attract consumers to come to stores and influence shopping behavior (Akter and Ashraf, 2016; Chang and 
Wang, 2014; Hosseini et al., 2014; Peter et al., 2018). Whereas image is the whole of beliefs, ideas, and impressions about an object that is owned by a person (Akter and Ashraf, 2016). The image will generate value that helps consumers in providing information. The image also makes consumers able to distinguish brands from competing brands, and a good image will generate positive consumer feelings. Consumers often see the product as a representative of the store image, a good product will certainly strengthen the store image. Besides, the price level can also be used to build a store image, price competitiveness will have a positive effect on repurchase intention and consumer loyalty. A study conducted by (Chang and Wang, 2014) found that to build a store image it is also necessary to look at the factors of exterior and interior design, service comfort, and facility comfort. Meanwhile, store image according to (Hosseini et al., 2014) has two elements, namely, functional elements such as store layout, location, price attributes, value for money and customer service, and psychological elements such as luxury, and store attractiveness.

Price Sensitivity (PS). The price level will affect consumer purchase intentions. With the tight competition in the retail industry, the price competition is also getting tougher. The presence of other retailers can damage the stability of prices that have been built. Increasingly competitive prices make price choices more diverse, this makes consumers more sensitive to prices because consumers believe that they have the right to get good treatment (Graciola et al., 2018). This will affect purchasing decisions because consumers are increasingly aware of the many alternatives available and believe that consumers deserve proper treatment (Lee and Fay, 2017).

\section{Hypothesis Development.}

Effect of price fairness image on OSPI. According to (Nguyen and Meng, 2016) price has two opposite sides. From the consumer's point of view, price is considered a cost so that consumers expect to get the lowest possible price. On the contrary, from the retail side, they want high prices to get a profit. Therefore, a policy that regulates this balance is needed. According to (Graciola et al., 2018), consumers will feel fair if there is price transparency. Price transparency can be done by including clear price tags and pricing policies. The role of perceived price fairness is very important in the consumer buying decision process. An empirical study conducted by (Narwal and Nayak, 2019) stated that retailers must treat all consumers fairly, with the same price charge. If retailer is unfairly, consumers will reduce consumer trust and caused a negative response (Hinner, 2016). When retail store prices are considered fair or reasonable based on the price range that consumers expect, then consumers tend to form a positive attitude towards prices in retail stores and this will have an impact on increasing OSPI (Chang and Wang, 2014; Graciola et al., 2018).

H1: Price fairness image effects positively on OSPI.

Effect of price pleasure image on OSPI. Emotions can be categorized into two, namely positive emotions and negative emotions (Graciola et al., 2018). Positive emotions will emerge when consumer expectations are met while shopping (Jin et al., 2016). Retailers can create positive emotions, for example by giving surprises (Ludwig et al., 2017). When 
consumer expectations are met, consumer pleasure tends to increase. A pleasant experience during shopping will encourage positive feelings. Studies conducted by (Chang and Wang, 2014), and (Graciola et al., 2018) found that the more pleasure consumers are when shopping, the more the price image of retail stores increases.

H2: Price pleasure image effects positively on OSPI.

Effect of price rewards image on OSPI. There are two kinds of awards that can be provided by retailers, namely monetary and non-monetary. Previous studies stated retailers through rewards, both monetary (such as price discounts, cashback) and non-monetary (such as sweepstakes, gifts) will increase OSPI (Büttner et al., 2014). Consumers have a short-term memory in remembering prices, so non-monetary rewards should not be used as a strategy to bring in consumers and get big profits. Nevertheless, (Santini et al., 2015) in their study found that attractive promotions will affect purchasing behavior. The findings previous study conducted by (Chang and Wang, 2014) showed different results. A study about the apparel industry found that rewards, both monetary and non-monetary, were not supported to affect OSPI. This is due to the uniqueness of the object under study. Apparel products for each store can be different so that consumers cannot directly compare the prices of products from one store to another.

H3: Price rewards image effects positively on OSPI.

Effect of price value image on OSPI. The price value image is formed by consumer evaluation of price level and product quality. The stronger the value of money when doing transactions, the more it has a positive impact, and with lower prices, consumers will increase shopping intentions (Graciola et al., 2018). This statement is supported by a study conducted by (Chang and Wang, 2014) which stated that if the consumer perceived product quality is higher than the price of the product, it will increase the consumer's perceived price value. The higher the price value received by consumers, the higher the OSPI.

H4: Price value image effects positively on OSPI.

Effect of OSPI on repurchase intention. A price is a tool that retailers use to deal with the market, both to retain and attract new customers. Consumers often make purchase decisions based on the perceived value of money and price information that has an impact on repurchase intentions (Paramananda and Sukaatmadja, 2018). The selection of retail stores and repurchase intentions are driven by the perceived price rather than the actual price (Chang and Wang, 2014; Paramananda and Sukaatmadja, 2018). When making repeat purchases, consumers will compare prices based on previous purchasing experiences (Uslu and Huseynli, 2018). Previous studies found that OSPI has a direct effect on repurchase intention (Chang and Wang, 2014; Graciola et al., 2018).

H5: OSPI effects positively on repurchase intention.

Store image as a moderating variable. Store image is needed to attract consumer trust in stores and carry out shopping activities. Previous studies (Belwal and Belwal, 2017) stated 
that 16 factors influence the image of the store, namely, the availability of parking facilities, cleanliness of the shop, the availability of prayer rooms, merchandise, support services, consumer price perceptions, the purchasing experience, shopping convenience, implementation of the marketing mix, after-sales service, repurchase experience, consumer perceptions of quality, product variants, courtesy of employees, availability of ATMs, and efficiency at the checkout when making payments. The higher the shop image, the stronger the OSPI influence on future repurchase intentions (Chang and Wang, 2014).

H6: Store image moderates the influence of OSPI on repurchase intentions.

Price Sensitivity as a moderating variable. Previous studies stated that consumer awareness of the price and product quality of competitors will determine the level of price sensitivity (Verma et al., 2019). Price sensitivity exists because the retail sector is in a position of tight price competition. Consumers will be reluctant to make purchases if prices are perceived to be high (Uslu and Huseynli, 2018). The lower the price, it will encourage consumers to buy products and encourage repurchase intention. Another study found a moderating role of the price sensitivity variable which strengthens the effect of OSPI on repurchase intention (Graciola et al., 2018).

H7: Price sensitivity moderates the influence of OSPI on repurchase intentions.

Conceptual framework. This research modifies two previous research models (Chang and Wang, 2014; Graciola et al., 2018).

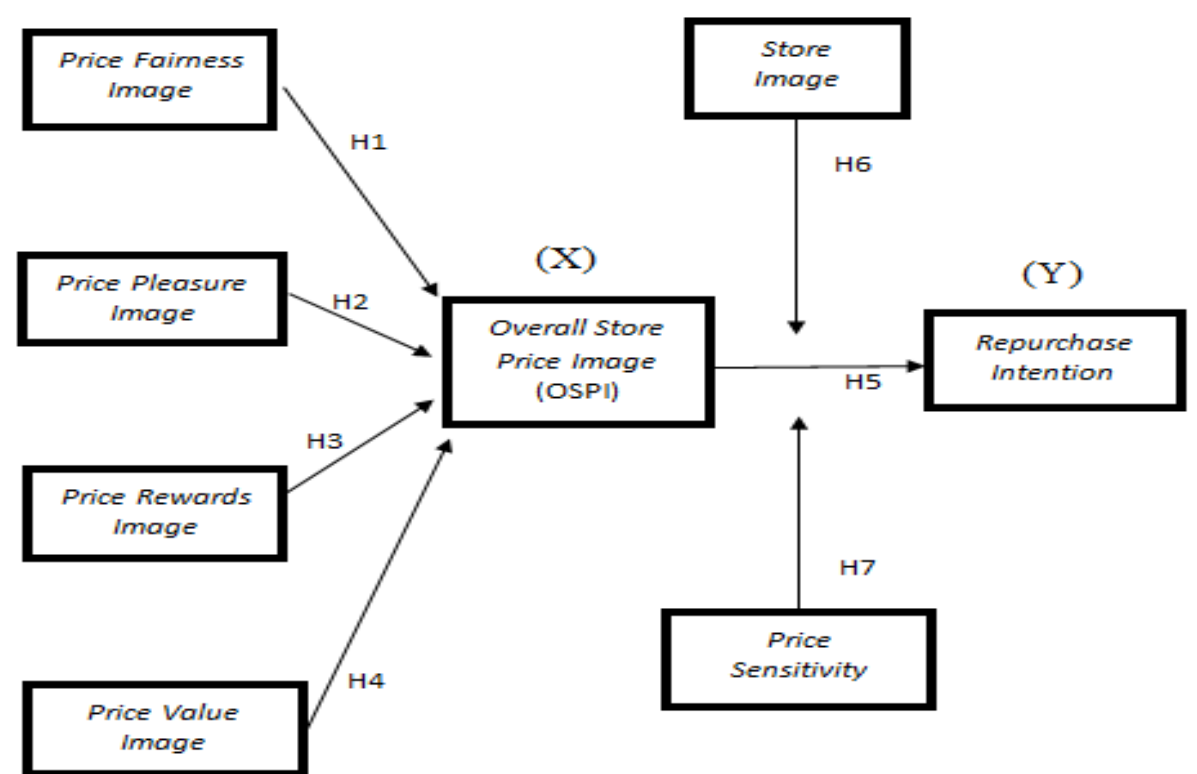

Figure 1. Research Model

Source: (Chang and Wang, 2014); (Graciola et al., 2018). 


\section{METHODS}

To collect data, the study employed a cross-sectional survey research design using a structured questionnaire and a purposive sampling method. The research instrument was translated from previous research into Bahasa by a professional translation agency. The measurement scale of the research instrument used a 5-point Likert scale, from strongly disagree (score 1) to strongly agree (score 5). The criteria for recruited respondents were consumers who have experience shopping at Pamela 6 mini-market, Minomartani, Yogyakarta. To reduce memory bias, respondents recruited were consumers who had made purchases within the last six months. The questionnaire was distributed to 450 respondents through an offline survey.

Data analysis was processed using Partial Least Square (SEM-PLS). In the SEMPLS, there are two test model, the measurement model (outer model), and a structural model (inner model). The outer model was used to test construct validity and instrument reliability. The goodness of fit model is determined by Cronbach's alpha and composite reliability (consistency of internal reliability), outer loading and AVE (convergent validity), cross-loading, and The Fornell-Larcker criterion (discriminant validity). The inner model was used to verify the hypothesis. The inner model assessment shows the value of path coefficients $(B)$, coefficient of determination $\left(\mathrm{R}^{2}\right.$ value), effect size ( $\mathrm{f}^{2}$ value), prediction relevance (Stone-Geisser's $\mathrm{Q}^{2}$ value), and significant path (p-value) (Ghozali and Latan, 2015). Moderation test classification according to (Sharma et al., 1981) is divided into four, a namely pure moderator, homologize moderator, quasi moderator, and predictor.

Table 1. Classification of Moderation Types

\begin{tabular}{l|l|l}
\hline \multicolumn{1}{c|}{ Description } & 及 2 & \multicolumn{1}{|c}{ 3 3 } \\
\hline Pure Moderator & Non-significant & Significant \\
\hline Homologiser Moderator & Non-significant & Non-significant \\
\hline Quasi Moderator & Significant & Significant \\
\hline Predictor & Significant & Non-significant \\
\hline
\end{tabular}

Source: (Sharma et al., 1981)

Table 1 shows that pure moderator is the variable purely as a moderating variable. If the variable has the potential to become a moderating variable, it is called a moderator homologous. A quasi moderator occurs when the variable moderates the relationship between the independent variable and the dependent variable which also becomes the independent variable. The predictor variable is a variable that only acts as an intervening, exogenous, antecedent, independent variable in the proposed research model (Sharma et al., 1981).

\section{RESULTS AND DISCUSSION}

Demographic characteristics. A total of 450 questionnaires were distributed to respondents. Of these, only 423 questionnaires can be processed, while 27 questionnaires cannot be processed further because of incomplete answered. Table 2 shows that the 
shopping frequency is dominated by consumers who have spent one to five times in the last six months $(48.7 \%)$. The majority of consumers in this study were women $(68.3 \%)$, aged between 20 and 34 years (45.2\%). The most recent consumer education level is a high school (54.6\%) and monthly expenditures of more than one million to three million Rupiah $(39.5 \%)$. The following is Table 2 that contains details of the study result of consumer profiles:

Table 2. Respondent Profile

\begin{tabular}{l|c|c}
\hline \multicolumn{1}{c|}{ Profile } & Frequency (people) & Percentage (\%) \\
\hline Shopping frequency & 206 & $48,7 \%$ \\
Between 1 and 5 times & 121 & $28,6 \%$ \\
Between 6 and 10 times & 96 & $22,7 \%$ \\
More than 10 times & 289 & \\
Gender: & 134 & $68,3 \%$ \\
Woman & & $31,7 \%$ \\
Man & 67 & $15,8 \%$ \\
Age: & 191 & $45,2 \%$ \\
Less than 20 years & 93 & $22 \%$ \\
Between 20 and 34 years & 72 & $17 \%$ \\
Between 35 and 49 years & & \\
More than 49 years & 231 & $54,6 \%$ \\
Education: & 173 & $40,9 \%$ \\
High school & 19 & $4,5 \%$ \\
Undergraduate & & \\
Postgraduate & 117 & $27,7 \%$ \\
Monthly shopping needs: & 167 & $39,5 \%$ \\
Less than IDR 1.000.000 & 86 & $20,3 \%$ \\
Between IDR 1.000.001 and IDR 3.000.000 & 42 & $9,9 \%$ \\
Between IDR 3.000.001 and IDR 5.000.000 & 11 & $2,6 \%$ \\
Between IDR 5.000.001 and IDR 7.000.000 & & \\
More than IDR 7.000.000 & & \\
\hline
\end{tabular}

Outer Model. Based on the results of the outer model test, it can be stated that all the research instruments are valid and reliable. The following is Table 3 shows the summary of the outer model test results:

Table 3. Summary of Outer Model Test Result

\begin{tabular}{|c|c|c|c|c|c|}
\hline \multirow[t]{2}{*}{ Variable } & \multirow[t]{2}{*}{$\begin{array}{l}\text { Indicator } \\
\text { code }\end{array}$} & \multicolumn{2}{|c|}{$\begin{array}{l}\text { Convergent } \\
\text { Validity }\end{array}$} & \multicolumn{2}{|c|}{$\begin{array}{l}\text { Internal Consistency } \\
\text { Reliability }\end{array}$} \\
\hline & & $\begin{array}{l}\text { Outer } \\
\text { Loadings }\end{array}$ & AVE & $\begin{array}{l}\text { Cronbach's } \\
\text { Alpha }\end{array}$ & $\begin{array}{l}\text { Composite } \\
\text { Reliability }\end{array}$ \\
\hline \multirow{3}{*}{$\begin{array}{l}\text { Overall Store } \\
\text { Price Image } \\
\text { (OSPI) }\end{array}$} & OSPI1 & 0,857 & \multirow[t]{3}{*}{0,678} & \multirow[t]{3}{*}{0,762} & \multirow[t]{3}{*}{0,863} \\
\hline & OSPI2 & 0,801 & & & \\
\hline & OSPI3 & 0,810 & & & \\
\hline \multirow{5}{*}{$\begin{array}{l}\text { Price Fairness } \\
\text { Image } \\
(\mathrm{PFI})\end{array}$} & PF4 & 0,849 & \multirow[t]{5}{*}{0,733} & \multirow[t]{5}{*}{0,909} & \multirow[t]{5}{*}{0,932} \\
\hline & PF5 & 0,875 & & & \\
\hline & PF6 & 0,862 & & & \\
\hline & PF7 & 0,846 & & & \\
\hline & PF8 & 0,849 & & & \\
\hline
\end{tabular}


Sihotang and Ellyawati: Overall Store Price Image (OSPI) ...

\begin{tabular}{|c|c|c|c|c|c|}
\hline \multirow{10}{*}{$\begin{array}{l}\text { Price Pleasure } \\
\text { Image } \\
(\mathrm{PPI})\end{array}$} & PP9 & 0,710 & \multirow[t]{10}{*}{0,596} & \multirow[t]{10}{*}{0,925} & \multirow[t]{10}{*}{0,936} \\
\hline & PP10 & 0,776 & & & \\
\hline & PP11 & 0,762 & & & \\
\hline & PP12 & 0,768 & & & \\
\hline & PP13 & 0,805 & & & \\
\hline & PP14 & 0,779 & & & \\
\hline & PP15 & 0,789 & & & \\
\hline & PP16 & 0,804 & & & \\
\hline & PP17 & 0,806 & & & \\
\hline & PP18 & 0,712 & & & \\
\hline \multirow{3}{*}{$\begin{array}{l}\text { Price Rewards } \\
\text { Image } \\
(\mathrm{PRI})\end{array}$} & PR19 & 0,941 & \multirow[t]{3}{*}{0,813} & \multirow[t]{3}{*}{0,883} & \multirow[t]{3}{*}{0,928} \\
\hline & PR20 & 0,817 & & & \\
\hline & PR21 & 0,941 & & & \\
\hline \multirow{3}{*}{$\begin{array}{l}\text { Price Value } \\
\text { Image } \\
(\mathrm{PVI})\end{array}$} & PV22 & 0,849 & \multirow[t]{3}{*}{0,724} & \multirow[t]{3}{*}{0,809} & \multirow[t]{3}{*}{0,887} \\
\hline & PV23 & 0,874 & & & \\
\hline & PV24 & 0,829 & & & \\
\hline \multirow{8}{*}{$\begin{array}{l}\text { Repurchase } \\
\text { Intentions (RI) }\end{array}$} & RI25 & 0,745 & \multirow[t]{8}{*}{0,603} & \multirow[t]{8}{*}{0,906} & \multirow[t]{8}{*}{0,924} \\
\hline & RI26 & 0,778 & & & \\
\hline & RI27 & 0,820 & & & \\
\hline & RI28 & 0,805 & & & \\
\hline & RI29 & 0,803 & & & \\
\hline & RI30 & 0,752 & & & \\
\hline & RI31 & 0,719 & & & \\
\hline & RI32 & 0,784 & & & \\
\hline
\end{tabular}

Table 3 shows that Cronbach's alpha value and composite reliability for each research instrument is greater than 0.7. This shows that all the research instruments employed are reliable. Outer loading value greater than 0.7 indicates the increasingly important role in explaining the factor matrix. Meanwhile, the AVE value>0.5 indicates that on average the variable can explain more than half of the indicator variance. All values indicate that the construct has a high level of consistency of internal reliability, and reliable convergent validity.

Table 4. Cross Loadings

\begin{tabular}{c|c|c|c|c|c|c}
\hline Indicator & OSPI & PFI & PPI & PRI & PVI & RI \\
\hline OSPI1 & $\mathbf{0 . 8 5 7}$ & 0.449 & 0.528 & 0.355 & 0.556 & 0.569 \\
\hline OSPI2 & $\mathbf{0 . 8 0 1}$ & 0.600 & 0.553 & 0.300 & 0.391 & 0.462 \\
\hline OSPI3 & $\mathbf{0 . 8 1 0}$ & 0.381 & 0.436 & 0.318 & 0.509 & 0.598 \\
\hline PF4 & 0.482 & $\mathbf{0 . 8 4 9}$ & 0.485 & 0.125 & 0.428 & 0.405 \\
\hline PF5 & 0.510 & $\mathbf{0 . 8 7 5}$ & 0.542 & 0.140 & 0.414 & 0.410 \\
\hline PF6 & 0.498 & $\mathbf{0 . 8 6 2}$ & 0.550 & 0.181 & 0.375 & 0.400 \\
\hline PF7 & 0.488 & $\mathbf{0 . 8 4 6}$ & 0.534 & 0.162 & 0.364 & 0.413 \\
\hline PF8 & 0.483 & $\mathbf{0 . 8 4 9}$ & 0.578 & 0.231 & 0.431 & 0.445 \\
\hline PP9 & 0.419 & 0.481 & $\mathbf{0 . 7 1 0}$ & 0.172 & 0.381 & 0.282 \\
\hline PP10 & 0.520 & 0.523 & $\mathbf{0 . 7 7 6}$ & 0.252 & 0.416 & 0.424 \\
\hline PP11 & 0.408 & 0.501 & $\mathbf{0 . 7 6 2}$ & 0.206 & 0.396 & 0.372 \\
\hline PP12 & 0.564 & 0.506 & $\mathbf{0 . 7 6 8}$ & 0.226 & 0.466 & 0.476 \\
\hline PP13 & 0.565 & 0.517 & $\mathbf{0 . 8 0 5}$ & 0.279 & 0.462 & 0.298 \\
\hline PP14 & 0.566 & 0.525 & $\mathbf{0 . 7 7 9}$ & 0.243 & 0.440 & 0.497 \\
\hline
\end{tabular}


Sihotang and Ellyawati: Overall Store Price Image (OSPI) ...

\begin{tabular}{c|l|l|l|l|l|l}
\hline PP15 & 0.339 & 0.428 & $\mathbf{0 . 7 8 9}$ & 0.160 & 0.274 & 0.272 \\
\hline PP16 & 0.413 & 0.478 & $\mathbf{0 . 8 0 4}$ & 0.155 & 0.324 & 0.352 \\
\hline PP17 & 0.405 & 0.436 & $\mathbf{0 . 8 0 6}$ & 0.192 & 0.354 & 0.350 \\
\hline PP18 & 0.391 & 0.395 & $\mathbf{0 . 7 1 2}$ & 0.219 & 0.301 & 0.358 \\
\hline PR19 & 0.334 & 0.136 & 0.221 & $\mathbf{0 . 9 4 1}$ & 0.249 & 0.241 \\
\hline PR20 & 0.385 & 0.254 & 0.310 & $\mathbf{0 . 8 1 7}$ & 0.309 & 0.306 \\
\hline PR21 & 0.337 & 0.130 & 0.221 & $\mathbf{0 . 9 4 1}$ & 0.246 & 0.240 \\
\hline PV22 & 0.513 & 0.438 & 0.460 & 0.248 & $\mathbf{0 . 8 4 9}$ & 0.463 \\
\hline PV23 & 0.525 & 0.402 & 0.407 & 0.206 & $\mathbf{0 . 8 7 4}$ & 0.513 \\
\hline PV24 & 0.474 & 0.356 & 0.429 & 0.321 & $\mathbf{0 . 8 2 9}$ & 0.532 \\
\hline RI25 & 0.559 & 0.469 & 0.489 & 0.238 & 0.494 & $\mathbf{0 . 7 4 5}$ \\
\hline RI26 & 0.521 & 0.332 & 0.377 & 0.184 & 0.422 & $\mathbf{0 . 7 7 8}$ \\
\hline RI27 & 0.576 & 0.367 & 0.417 & 0.236 & 0.489 & $\mathbf{0 . 8 2 0}$ \\
\hline RI28 & 0.511 & 0.368 & 0.451 & 0.259 & 0.484 & $\mathbf{0 . 8 0 5}$ \\
\hline RI29 & 0.535 & 0.384 & 0.433 & 0.240 & 0.551 & $\mathbf{0 . 8 0 3}$ \\
\hline RI30 & 0.446 & 0.389 & 0.375 & 0.184 & 0.383 & $\mathbf{0 . 7 5 2}$ \\
\hline RI31 & 0.440 & 0.342 & 0.292 & 0.245 & 0.360 & $\mathbf{0 . 7 1 9}$ \\
\hline RI32 & 0.497 & 0.352 & 0.367 & 0.246 & 0.443 & $\mathbf{0 . 7 8 4}$ \\
\hline
\end{tabular}

Table 5. Fornell-Larcker

\begin{tabular}{l|c|c|c|c|c|c}
\hline \multicolumn{1}{c|}{ Variabel } & OSPI & PFI & PPI & PRI & PVI & RI \\
\hline $\begin{array}{l}\text { Overall Store Price } \\
\text { Image }\end{array}$ & $\mathbf{0 , 8 2 3}$ & & & & & \\
\hline Price Fairness Image & 0,575 & $\mathbf{0 , 8 5 6}$ & & & & \\
\hline Price Pleasure Image & 0,613 & 0,628 & $\mathbf{0 , 7 7 2}$ & & & \\
\hline Price Rewards Image & 0,395 & 0,198 & 0,280 & $\mathbf{0 , 9 0 1}$ & & \\
\hline Price Value Image & 0,593 & 0,470 & 0,507 & 0,301 & $\mathbf{0 , 8 5 1}$ & \\
\hline Repurchase Intentions & 0,662 & 0,484 & 0,519 & 0,295 & 0,590 & $\mathbf{0 , 7 7 7}$ \\
\hline
\end{tabular}

Table 4 and Table 5 show the construct discriminant validity. The study resulted in cross-loading values for each variable greater than 0.7 . The Fornell-Larcker criterion value has met the indicator validity. This can be seen from the AVE root value which is greater than AVE root values of other variables. This means that the discriminant validity of the indicator is fulfilled.

Table 6. Q Square $\left(\mathrm{Q}^{2}\right)$

\begin{tabular}{l|c}
\hline \multicolumn{1}{c|}{ Variable } & $\mathbf{Q}^{\mathbf{2}}$ \\
\hline Overall Store Price Image & 0,346 \\
\hline Repurchase Intentions & 0,241 \\
\hline
\end{tabular}

Table 6 shows the value of Stone-Geisser's $Q^{2}$ used to predict the model or measure how well the observed value was generated by the model with a value of $0<Q^{2}<1$. This study produces a $\mathrm{Q}^{2}$ (OSPI) value of 0.346 and $\mathrm{Q}^{2}$ (repurchase intention) of 0.241 . Thus, it means that the predictive relevance of this research is fulfilled. 


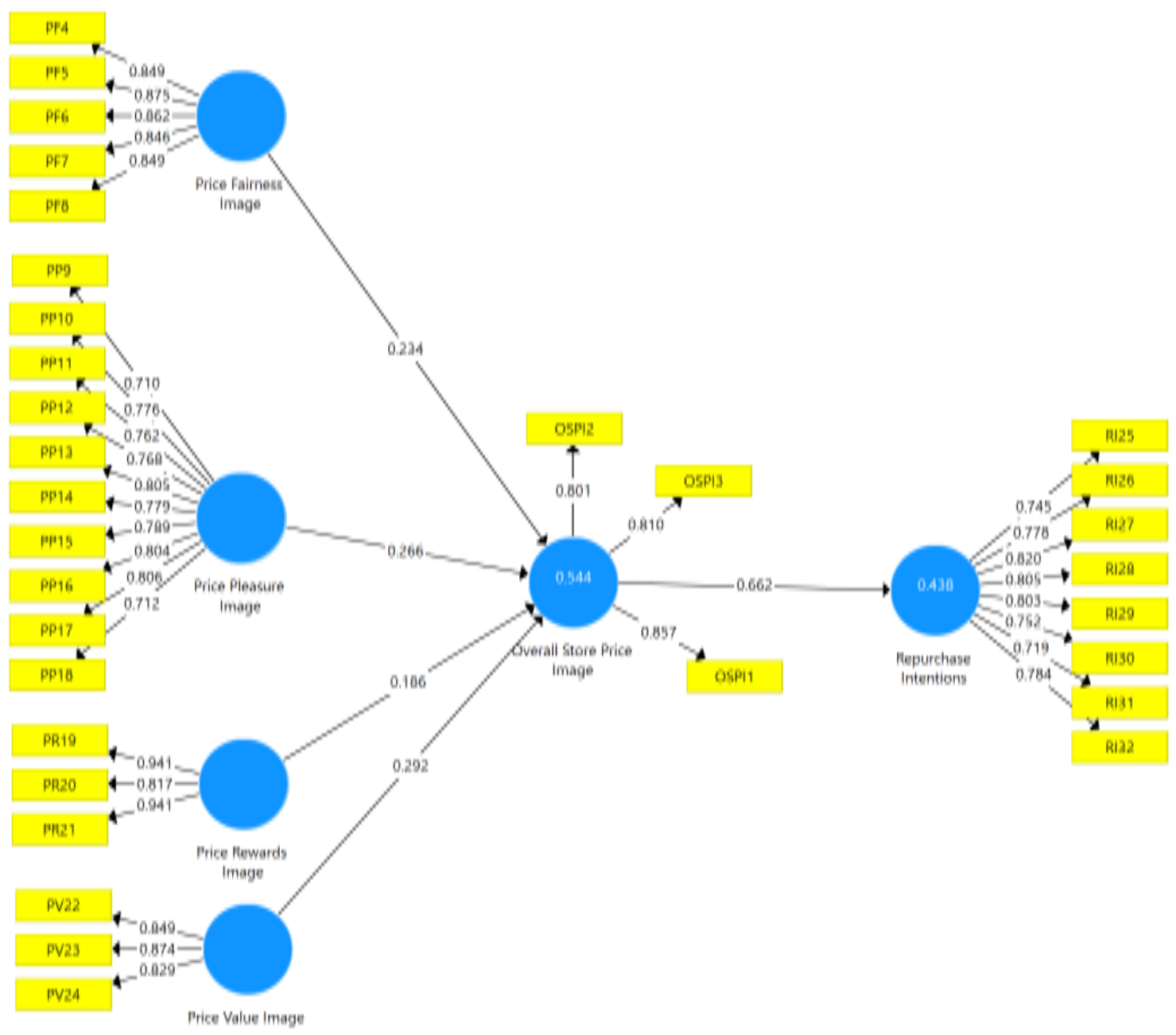

Figure 2. Structural Model

The value of $\mathrm{R}^{2}$ in Figure 2 shows that the dimensions of PVI, PRI, PPI, PFI can explain $54.4 \%$ of changes in the OSPI variable, while the rest $(45.6 \%)$ is explained by variables, not included in the model. The OSPI variable can explain $43.8 \%$ of changes in the repurchase intention variable, while the rest $(56.2 \%)$ is explained by variables not included in the model.

Table 7 summarizes the value of $\mathrm{f}^{2}$, which shows the effect when exogenous variables are removed. OSPI has a large effect size of 0.780 on repurchase intention. PFI has a small effect size on OSPI (0.069), PPI has a small effect size on OSPI (0.083), PRI has a small effect size on OSPI (0.068). PVI has a small effect size on OSPI $(0.127)$ 
Table 7. F Square $\left(\mathrm{F}^{2}\right)$

\begin{tabular}{c|c|c|c|c|c|c}
\hline Variable & OSPI & PFI & PPI & PRI & PVI & RI \\
\hline OSPI & & & & & & 0,780 \\
\hline PFI & 0,069 & & & & & \\
\hline PPI & 0,083 & & & & & \\
\hline PRI & 0,068 & & & & & \\
\hline PVI & 0,127 & & & & & \\
\hline RI & & & & & & \\
\hline
\end{tabular}

Hypothesis testing. This study uses a 95\% confidence level with a p-value criterion of less than 0.05 and a t-statistic greater than 1.64 (Ghozali and Latan, 2015). Following are the results of this research hypothesis test:

Table 8. Structural Model Analysis

\begin{tabular}{c|l|c|c|c|c}
\hline Hypothesis & Path from/ to & $\beta$ & t-Statistics & p-Value & Result \\
\hline H1 & PFI $\rightarrow$ OSPI & 0,234 & 4,775 & 0,000 & Supported \\
\hline H2 & PPI $\rightarrow$ OSPI & 0,266 & 5,317 & 0,000 & Supported \\
\hline H3 & PRI $\rightarrow$ OSPI & 0,186 & 4,652 & 0,000 & Supported \\
\hline H4 & PVI $\rightarrow$ OSPI & 0,292 & 5,315 & 0,000 & Supported \\
\hline H5 & OSPI $\rightarrow$ RI & 0,662 & 19,798 & 0,000 & Supported \\
\hline
\end{tabular}

Based on the result as stated in Table 8, It can be concluded that the price fairness image has a positive and significant effect on OSPI (H1 supported). This finding is consistent with the research conducted by (Chang and Wang, 2014) and (Graciola et al., 2018). (Chang and Wang, 2014) in their study stated that when the price at a retail store is considered reasonable or within the expected price range, consumers will form a positive attitude towards the price at the retail store, and OSPI tends to increase. The study is in line with a study conducted by (Graciola et al., 2018). Their study stated that price transparency will increase consumer perceptions of justice. (Roth et al., 2017) also stated that product pricing by including a clear price tag and pricing policy will strengthen the store price image. This study found that the prices of the products offered were fair, acceptable, and reasonable. Stores also establish transparent pricing policies, such as identifiable price tags and promotional policies that can be clearly understood by customers.

Price pleasure image effects positively and significantly on OSPI (H2 supported). A past study stated that when product prices in retail stores offer positive feelings of consumption such as happiness while shopping, OSPI will also increase (Chang and Wang, 2014). Giving surprises such as price reductions can affect consumer responses to product prices (Ludwig et al., 2017). (Nguyen and Meng, 2016) stated that a fair price will make consumers feel satisfied and happy. This study found that consumers like the price offered by the retailer. Product prices that are listed at the price tag make consumers feel satisfied to be able to compare them with similar products. The promotion that the store offer is easy to understand which makes consumers happy and enthusiastic.

This study found that the price rewards image has a positive and significant effect on OSPI (H3 supported). This study is in line with a study conducted by (Büttner et al., 2014). 
To attract customers, the retailer provides monetary promotions such as price discounts on special days, and non-monetary promotions, such as giving shopping coupons, giving a free gift with certain purchase conditions. The results of this study indicate that incentives will increase price rewards image, and leads to affect OSPI positively. The findings of this study are not in line with the study conducted by (Chang and Wang, 2014). This difference result occurs because the previous research object is apparel products. This type of product is unique, and not all stores sell the same product, this makes it difficult for consumers to compare prices.

Price value image effects positively and significantly on OSPI (H4 supported). This study is consistent with the study of (Chang and Wang, 2014), and (Graciola et al., 2018). Their studies found that when perceived quality is higher than the product price, the price value image tends to increase. Furthermore, when the price value image is high, it will lead to increase OSPI. Price is important for consumers as a guide to measuring the suitability of the sacrifices that have been given, and the perceived benefits of the product (Kumar et al., 2016). This makes consumers maximize the value for money spent by seeking for better quality at lower prices (Paramananda and Sukaatmadja, 2018). This study is in line with a study conducted by (Kumar et al., 2016), and (Paramananda and Sukaatmadja, 2018) that stated consumers perceive that product prices are cheaper than expected, and save more money compared to other stores at the same product quality level. This makes consumers feel that shopping at the store is a profitable transaction.

The study found that OSPI affects positively on repurchase intention (H5 is supported). The high value of the OSPI dimension tends to affect consumer repurchase intentions positively. The study is in line with previous studies which stated that OSPI affects purchase repurchase intention (Chang and Wang findings, 2014; Graciola et al., 2018). According to (Roth et al., 2017), OSPI has complementary components such as ease of access to prices, price perception, price evaluation, perceived price level, and perceived monetary value. This study found that consumers' perceptions of product prices in these stores were attractive, reasonable, and cheaper than other stores. This causes consumers to be willing to recommend the shop to family and friends. When consumers are going to shop, they will consider the store in advance and even plan to shop frequently.

Figure 3 shows that the presence of the store image variable causes an increase in the $R^{2}$ value of the repurchase intention from 0,438 to 0.514 , while the $R^{2}$ value in the OSPI variable remains the same. This means that the OSPI and Store image variables affect simultaneously on repurchase intention by $51,4 \%$, and the rest is explained by other variables that are not included in the model.

Testing the store image as a moderating variable. Table 9 shows that store image affects repurchase intention (b2) positively, and significantly $(\mathrm{p}<0.05 ; \mathrm{c}=0.342)$. Meanwhile, the store image as a moderation effect did not significantly $(\mathrm{p}>0.05)$ affect the relationship between OSPI and repurchase intention (b3). Based on the study results, it was found that the store image variable was not a moderator variable but as an intervening variable that mediates the relationship between OSPI and repurchase intention (Sharma et al., 1981). Thus, hypothesis 6 is not supported. This study is different from a previous study that found store image strengthens the relationship between OSPI and repurchase intention (Chang and Wang, 2014). 


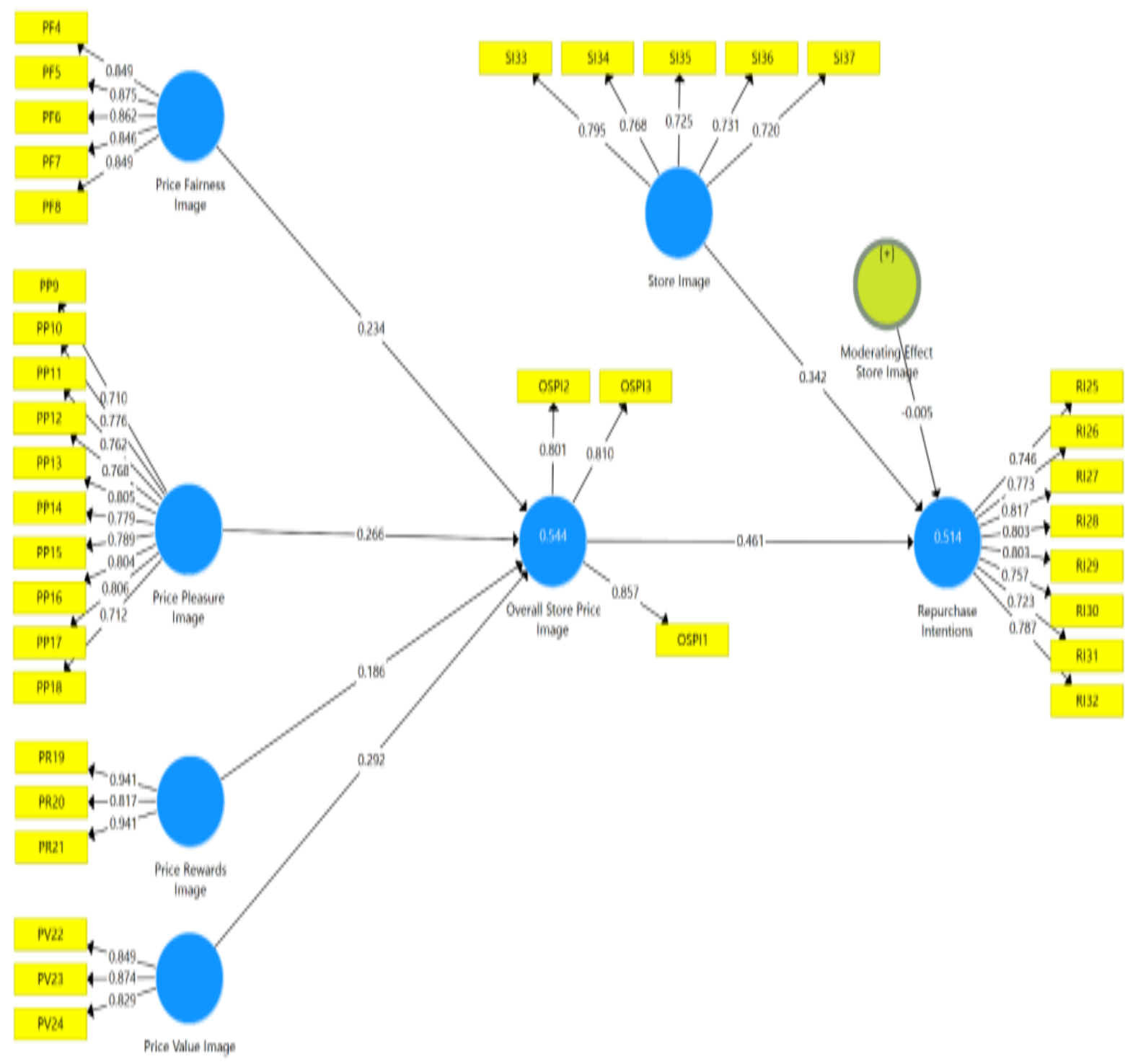

Figure 3. Test Result of Store Image as Moderating Variable 
Table 9. Moderation Effect Test Result for Store Image

\begin{tabular}{|c|c|c|c|c|c|}
\hline Hypothesis & Path Coefficients & $\boldsymbol{\beta}$ & $\begin{array}{c}\text { t-Statistics } \\
\text { (|O/STDEV|) }\end{array}$ & $\begin{array}{c}\text { p- } \\
\text { Value }\end{array}$ & Result \\
\hline \multirow[t]{7}{*}{ H6 } & $\begin{array}{l}\text { Moderating Effect SI } \rightarrow \\
\text { RI }\end{array}$ & $\begin{array}{c}- \\
0,00 \\
5\end{array}$ & 0,182 & 0,855 & $\begin{array}{l}\text { Non- } \\
\text { significant }\end{array}$ \\
\hline & OSPI $\rightarrow$ RI & $\begin{array}{c}0,46 \\
1\end{array}$ & 9,471 & 0,000 & Significant \\
\hline & $\mathrm{PFI} \rightarrow$ OSPI & $\begin{array}{c}0,23 \\
4\end{array}$ & 4,875 & 0,000 & Significant \\
\hline & $\mathrm{PPI} \rightarrow$ OSPI & $\begin{array}{c}0,26 \\
6\end{array}$ & 5,264 & 0,000 & Significant \\
\hline & PRI $\rightarrow$ OSPI & $\begin{array}{c}0,18 \\
6\end{array}$ & 4,550 & 0,000 & Significant \\
\hline & PVI $\rightarrow$ OSPI & $\begin{array}{c}0,29 \\
2\end{array}$ & 5,143 & 0,000 & Significant \\
\hline & $\mathrm{SI} \rightarrow \mathrm{RI}$ & $\begin{array}{c}0,34 \\
2\end{array}$ & 6,934 & 0,000 & Significant \\
\hline
\end{tabular}

Testing price sensitivity as a moderating variable. Figure 4 shows that the presence of the PS variable causes an increase in the $\mathrm{R}^{2}$ value of the repurchase intention from 0.438 to 0.469 , while the $\mathrm{R}^{2}$ value in the OSPI variable remains the same. This means that the OSPI and price variables affect simultaneously on repurchase intention by $46.9 \%$, and the rest is explained by other variables that are not included in the model. 


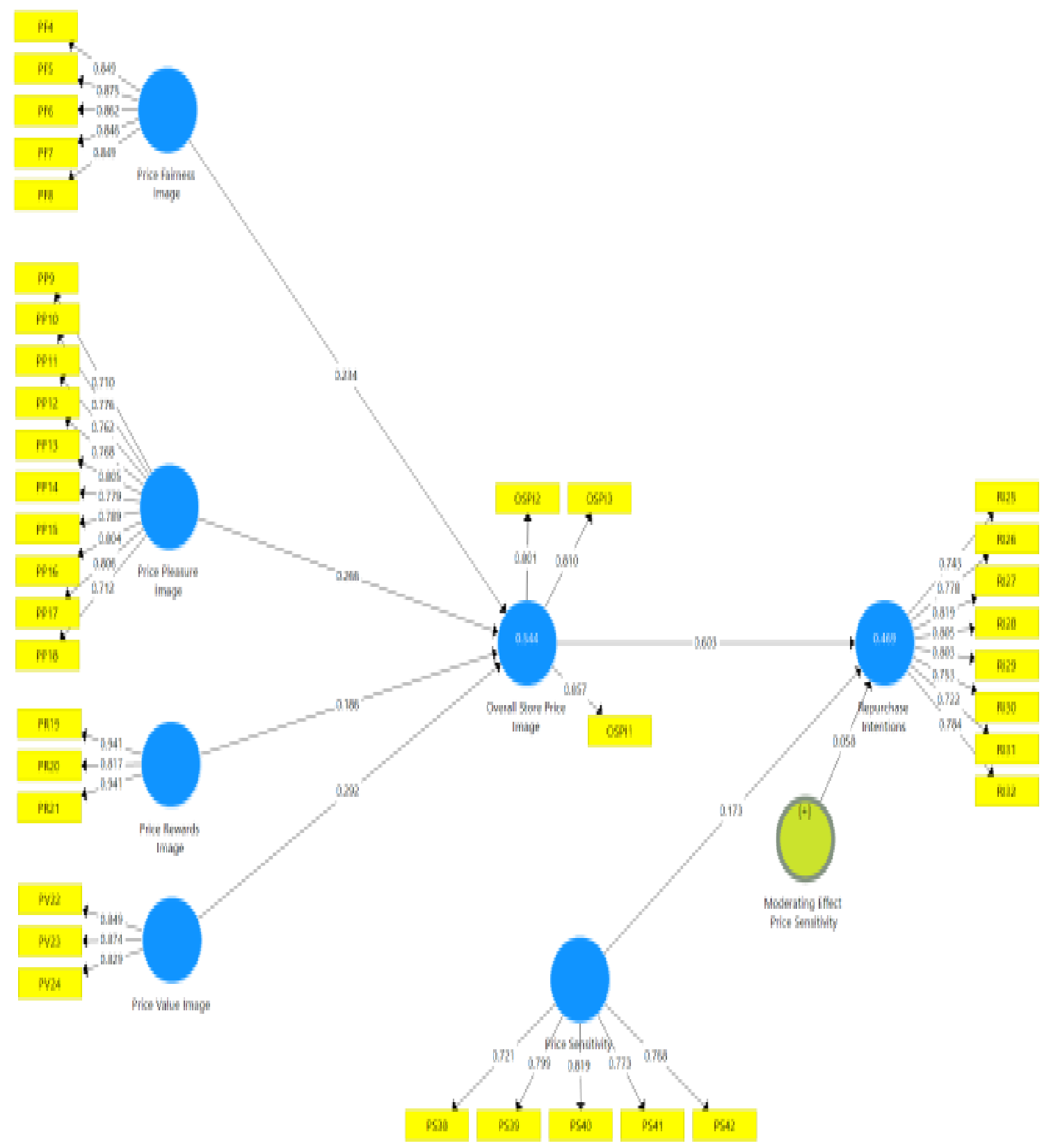

Figure 4. Test Result of Price Sensitivity as Moderating Variable

Table 10 shows that price sensitivity affects repurchase intention positively and significantly $(p<0.05 ; \beta=0.173)$. Meanwhile, the moderating effect of price sensitivity does not affect the relationship between OSPI and repurchase intention $(p>0.05)$. H7 is not supported. 
Table 10. Moderation effect of price sensitivity

\begin{tabular}{l|l|c|c|c|l}
\hline Hypothesis & \multicolumn{1}{|c|}{ Path Coefficients } & $\boldsymbol{\beta}$ & $\begin{array}{l}\text { t-Statistics } \\
(|\mathbf{O} / \mathbf{S T D E V}|)\end{array}$ & p-Value & Result \\
\hline \multirow{3}{*}{ H7 } & Moderating Effect PS $\rightarrow$ RI & 0,058 & 1,533 & 0,126 & $\begin{array}{l}\text { Non- } \\
\text { significant }\end{array}$ \\
\cline { 2 - 6 } & OSPI $\rightarrow$ RI & 0,603 & 14,236 & 0,000 & Significant \\
\cline { 2 - 6 } & PFI $\rightarrow$ OSPI & 0,234 & 4,934 & 0,000 & Significant \\
\cline { 2 - 6 } & PPI $\rightarrow$ OSPI & 0,266 & 5,245 & 0,000 & Significant \\
\cline { 2 - 6 } & PRI $\rightarrow$ OSPI & 0,186 & 4,426 & 0,000 & Significant \\
\cline { 2 - 6 } & PVI $\rightarrow$ OSPI & 0,292 & 5,544 & 0,000 & Significant \\
\cline { 2 - 6 } & PS $\rightarrow$ RI & 0,173 & 3,877 & 0,000 & Significant \\
\hline
\end{tabular}

Thus in this study, the price sensitivity variable is not a moderator variable but as an intervening variable that mediates the relationship between OSPI and repurchase intention (Sharma et al., 1981). This study is not in line with the past study, which found price sensitivity would strengthen the effect of OSPI on repurchase intention (Graciola et al., 2018).

\section{CONCLUSION}

The results of this study indicate that making consumers happy when shopping will increase price pleasure image. The frequent use of shops for monetary and non-monetary promotions proves that incentives increase price reward image. Consumers perceive that the prices of products in supermarkets are cheaper than what consumers think, thus saving money and of course, benefiting consumers. In other words, a cheaper product price with the same quality tends to increase price value image, which in turn has a positive effect on OSPI.

The study found that high price value image has a positive effect on OSPI. Consumers felt that the product prices were attractive, reasonable, and cheaper than other stores. This is the reason why consumers are willing to recommend the store to friends and family. Also, when consumers want to go shopping, consumers will consider shopping at the store and decide that they will shop frequently to the same store in the future.

An important study finding for future research is that store image and price sensitivity are not as moderating variables, instead of as intervening between the effect of OSPI on repurchase intention. This means that store image plays an important role because a good overall store price image (price value image, price pleasure image, price reward image, and price value image) does not directly make consumers willing to repurchase at the store, but consumer repurchase intention is influenced indirectly by OSPI through store image and price sensitivity. However, it still needs to be proven scientifically.

Managerial Implications. This study shows that all antecedent variables affect customer repurchase intention. Based on the study results, there are several determinants of OSPI that retailer needs to pay attention to achieve success. First, retailers need to concern about the customers' perceived fairness by paying attention to an unambiguous price tag so that consumers will put trust in the store. With the price tag, consumers can also compare prices 
with other stores so that it will satisfy consumers and keep consumers from switching behaviour. Second, the retailer needs to stimuli consumers with positive emotions by providing surprises such as regular promotions and a pleasant shopping environment. Because the Pamella 6 store is a local chain retail store that only relies on low prices, therefore in a tight competition like today, retailers should implement new technology by providing mobile application services to facilitate the consumer shopping process. This study also shows the importance of empowering employees as important information providers to optimize price communication and the benefits of existing products.

Research Limitations and Suggestions. The object of this research is limited to one retail store, therefore the results cannot be generalized to all categories of the retail store industry. For future research need to investigate different types of store formats. The study found that store image and price sensitivity are intervening variables. For further research, it is necessary to verify the influence of store image and price sensitivity as an intervening variable that mediates OSPI and repurchase intention. For better results, further research needs to add OSPI antecedents such as quality dimensions, perceived price levels, and symbolic dimensions.

\section{REFERENCES}

Akter, S., and Ashraf, E. (2016). Factors affecting repurchase intention of customers: in the context of retail chain store industry in Bangladesh. European Journal of Business and Management Www.Iiste.Org ISSN, 8(32), 40-47. www.iiste.org

Belwal, R., and Belwal, S. (2017). Factors affecting store image and the choice of hypermarkets in Oman. International Journal of Retail and Distribution Management, 45(6), 587-607. https://doi.org/10.1108/IJRDM-06-2015-0086.

BPS. (2014). Population projection by Province, 2010-2035 (thousand) (in Bahasa). BPS. https://www.bps.go.id/statictable/2014/02/18/1274/proyeksi-penduduk-menurutprovinsi-2010---2035.html.

Büttner, Oliver; Florack, Arnd; and Göritz, A. S. (2014). Shopping orientation and promotions. European Journal of Marketing.

CEIC. (2019). Indonesia retail sales growth, (in Bahasa). CEICDATA. https://www.ceicdata.com/id/indicator/indonesia/retail-sales-growth.

Chang, S. H., and Wang, K. Y. (2014). Investigating the antecedents and consequences of an overall store price image in retail settings. Journal of Marketing Theory and Practice, 22(3), 299-314. https://doi.org/10.2753/MTP1069-6679220305.

duniaindustri.com. (2015). Industrial data of minimarket, supermarket, hypermarket. (in Bahasa). duniaindustri. http://duniaindustri.com/downloads/data-industriminimarket-supermarket-hypermarket-di-indonesia/.

Ellyawati, J. (2017). Double deviation investigation of perceived service recovery justice: a study on the Indonesian airline industry. Journal of Applied Business Research, 33(6), 1263-1272.

Franjković, J., Štimac, H., \& Dujak, D. (2017). Retail price image managing: the role of household income and price image levels. 25th International Scientific Conference on Economic and Social Development - XVII International Social Congress (ISC2017) - Moscow, 30-31 October 2017, October, 171-180. 
Ghozali, Imam; and Latan, H. (2015). Partial least square: concept, technique, and application using SmartPLS 3.0 program for empirical research. (in Bahasa). Badan Penerbit Universitas Diponegoro. http://ailis.lib.unair.ac.id/opac/detailopac?id=108908.

Graciola, A. P., De Toni, D., de Lima, V. Z., and Milan, G. S. (2018). Does price sensitivity and price level influence store price image and repurchase intention in retail markets? Journal of Retailing and Consumer Services, 44(November 2017), 201213. https://doi.org/10.1016/j.jretconser.2018.06.014.

Hinner, M. B. (2016). Relationships and trust in perceiving price fairness: an exploratory stud. Economics and Business Review, 2 (16)(2), 54-73. https://doi.org/10.18559/ebr.2016.2.4.

Hosseini, Z., Jayashree, S., and Malarvizhi, C. (2014). Store image and its effect on customer perception of retail stores. Asian Social Science, 10(21), 223-235. https://doi.org/10.5539/ass.v10n21p223.

Jin, N. (Paul), Line, N. D., and Merkebu, J. (2016). The effects of image and price fairness: A consideration of delight and loyalty in the waterpark industry. International Journal of Contemporary Hospitality Management, 28(9), 1895-1914. https://doi.org/10.1108/IJCHM-03-2015-0094.

Jones, M. A., Reynolds, K. E., Arnold, M. J., Gabler, C. B., Gillison, S. T., and Landers, V. M. (2015). Exploring consumers' attitudes towards relationship marketing. Journal of Services Marketing, 29(3), 188-199. https://doi.org/10.1108/JSM-042014-0134.

Kimpel, M; and Friedrich, C. (2015). The right pricing strategy for offline retailers when expanding into the online sales channel. Journal of Business and Retail Management Research, 9(2), 54-68.

Koschmann, A., and Isaac, M. S. (2018). Retailer categorization: How store-format price image influences expected prices and consumer choices. Journal of Retailing, 94(4), 364-379. https://doi.org/10.1016/j.jretai.2018.08.001.

Kumar, A., Adlakha, A., and Mukherjee, K. (2016). Modeling of product sales promotion and price discounting strategy using fuzzy logic in a retail organization. Industrial Management and Data Systems, 116(8), 1418-1444. https://doi.org/10.1108/IMDS10-2015-0438.

Lee, S. H. (Shawn), and Fay, S. (2017). Why offer lower prices to past customers? Inducing favorable social price comparisons to enhance customer retention. Quantitative Marketing and Economics, 15(2), 123-163. https://doi.org/10.1007/s11129-017-9181-1.

Lombart, C., Louis, D., and Labbé-Pinlon, B. (2016). Price image consequences. Journal of Retailing and Consumer Services, 28, 107-116. https://doi.org/10.1016/j.jretconser.2015.09.001.

Ludwig, N. L., Heidenreich, S., Kraemer, T., and Gouthier, M. (2017). Customer delight: universal remedy or a double-edged sword? Journal of Service Theory and Practice, 27(1), 22-45. https://doi.org/10.1108/JSTP-08-2015-0197.

Narwal, P., \& Nayak, J. K. (2019). How consumers respond to social norms: an evidence from pay-what-you-want (PWYW) pricing. Journal of Consumer Marketing, 36(4), 494-505. https://doi.org/10.1108/JCM-05-2018-2677

Nguyen, A., and Meng, J. G. (2016). How source of funds affects buyer's judgments of 
price fairness and subsequent response. Journal of Product and Brand Management, 25(7), 710-720. https://doi.org/10.1108/JPBM-02-2016-1104.

Paramananda, N., and Sukaatmadja, I. P. G. (2018). The impact of price perception and brand image on customer satisfaction and repurchase intention. International Journal of Economics, Commerce and Management, 12(2), 59-73. https://doi.org/10.5937/poseko14-15894.

Peter, O. R., Oundo, B. H., and Lydiah, A. (2018). The effect of store image and price on store brand equity: Evidence from Supermarkets in Kenya. IOSR Journal of Business and Management, 20(10), 15-23. https://doi.org/10.9790/487X2010021523.

Primadhyta, S. (2016). Businessmen protest the rules of foreign investors in the retail industry. (in Bahasa). https://www.cnnindonesia.com/ekonomi/2016102419391192-167633/pengusaha-protes-aturan-investor-asing-di-industri-ritel.

Rachmatunnisa. (2018). Allegedly closed, this is what happened to MatahariMall. (in Bahasa). In detikInet. detikInet. https://inet.detik.com/business/d-4312399/didugatutup-ini-yang-sebenarnya-terjadi-pada-mataharimall.

Rosyadi, S. A. (2017). Several reasons why 7-Eleven outlets have closed in Indonesia. (in Bahasa). IDN Times. https://www.idntimes.com/news/indonesia/sarah-aprilianarosyadi/gerai-7-eleven-tutup-di-indonesia-c1c2.

Roth, S., Himbert, L., and Zielke, S. (2017). Does unit pricing influence store price image dimensions and shopping intentions for retail stores? European Journal of Marketing, 51(7-8), 1396-1413. https://doi.org/10.1108/EJM-12-2015-0834.

Santini, F. de O., Sampaio, C. H., Perin, M. G., and Vieira, V. A. (2015). An analysis of the influence of discount sales promotion in consumer buying intent and the moderating effects of attractiveness. Revista de Administração, 50(4), 416-431. https://doi.org/10.5700/rausp1210.

Seim, K., Vitorino, M. A., and Muir, D. M. (2017). Do consumers value price transparency? In Quantitative Marketing and Economics (Vol. 15, Issue 4). Quantitative Marketing and Economics. https://doi.org/10.1007/s11129-017-9193$\mathrm{X}$.

Sharma, Subhash; Durand, Richard M.; and Gur-Arie, O. (1981). Identification and Analysis of Maderator Variables. Journal of Marketing Research, XVIII, 291-300.

Tarhini, A., Deh, R. M., Al-Busaidi, K. A., Mohammed, A. B., and Maqableh, M. (2017). Factors influencing students' adoption of e-learning: A structural equation modeling approach. Journal of International Education in Business, 10(2), 164-182. https://doi.org/10.1108/JIEB-09-2016-0032.

Uslu, A., and Huseynli, B. (2018). Impact of price sensitivity on repurchase intention in terms of personality features. International Journal of Economic and Administrative Studies, 515-532. https://doi.org/10.18092/ulikidince.434866.

Verma, S., Guha, A., Biswas, A., and Grewal, D. (2019). Are low price and price matching guarantees equivalent? The effects of different price guarantees on consumers' evaluations. Journal of Retailing, 95(3), 99-108. https://doi.org/10.1016/j.jretai.2019.07.001 